\title{
LEARNING FROM THE SALES CONVERSION RATE THROUGHOUT ITS PRODUCT LIFE CYCLE ANALYSIS: A CASE OF STUDY FOR THE SPANISH AUTOMOTIVE SECTOR
}

\author{
Manuela Saco', Aida Galiano ${ }^{2}$, Vicente Rodríguez ${ }^{3}$
}

\footnotetext{
1 Universidad San Pablo CEU, Facultad de Ciencias Económicas y Empresariales, Spain, sacvaz@ceu.es;

2 Universidad Internacional de la Rioja (UNIR), Facultad de Empresa y Comunicación, Spain, ORCID: 0000-00021587-6262, aida.galiano@unir.net;

$3 \quad$ Universidad Internacional de la Rioja (UNIR), Facultad de Empresa y Comunicación, Spain, vicente.rodriguez@ unir.net.
}

\begin{abstract}
The scientific literature has not considered that the conversion rate in sales could have an irregular behaviour throughout the Product Life Cycle (PLC). The main contribution of this article is to reveal this unequal behaviour of the conversion rate in each of the phases of the PLC and highlight the advantages that the knowledge of this behaviour brings to Marketing and sales departments. In the empirical analysis carried out 157,960 clients have acquired 27,831 vehicles during 42 months considering a national network of car dealerships. We use ARIMA methodology to study the evolution of the time series considered. The results show a countercyclical behaviour of the conversion rate variable and an evolution pattern that fluctuates with the cycle in the case of the analysis of the clients assisted variable. Contrary to what might be expected, the conversion rate variable increases significantly in the launch phase and decreases significantly in the growth phase. This unknown performance of the conversion rate can be used in business decisions by the Marketing and sales departments to improve their efficiency. The conclusions obtained in this investigation can be an advance in the use of the PLC in analysing the evolution of the company, promoting a development of knowledge in both the academic field and in the business world. This work has theoretical and practical implications that can help business management. This research is an exciting scientific challenge that aims to develop numerous and important practical applications, with the aim of combining the management of the PLC with the conversion rate in sales, aspects that are closely related in the business field.
\end{abstract}

Keywords: Conversion rate in sales, Product Life Cycle, consumer behaviour, car dealerships, clients assisted.

JEL Classification: M31, C22, C25.

APA Style Citation: Saco, M., Galiano, A., \& Rodríguez, V. (2020). Learning from the Sales Conversion Rate throughout its Product Life Cycle Analysis: A Case of Study for the Spanish Automotive Sector. E\&M Economics and Management, 23(1), 184-198. https://doi.org/10.15240/tul/001/2020-1-013

\section{Introduction}

The conversion rate in sales is a fundamental parameter to assess the performance of the Marketing and sales departments. Fisher (2013) claims that when customers visit a store, retailers try to convert traffic by making sure there is the right product, in the right place, at the right time, and with the right price. At that moment, the conversion rate is a crucial value to measure the effectiveness of the Marketing policies and commercial teams in relation to consumer behaviour. 
The conversion rate $(\mathrm{CR})$ measures the ratio between the total number of visitors entering an establishment and those who make a purchase (on a daily, monthly, quarterly and annual basis). The conversion rate can also be useful to analyse the evolution of the commercial efficiency in a business or to compare similar establishments in which the conversion rates are significantly different. Somehow, the efficiency depends on the adequate commercial performance of the sales team, trying to attract the largest number of potential buyers visiting the establishment (Rodríguez, Olarte-Pascual, \& Saco, 2017). Therefore, the conversion rate grows with an excellent customer service and better execution of the store processes.

Product Life Cycle (PLC) is a relevant concept in the commercialization process, in the consumer behaviour analysis and in the study of the accommodation to the changes that take place in a business and competition environment (Ferreira et al., 2017). These changes condition the design of the Marketing strategy, therefore, the knowledge of the behaviour of the market, contributing to reduce the level of uncertainty and improving Marketing decisions (BriedeWestermeyer et al., 2016, p. 622). In this sense, Miquel and Molla (1982) point out that: "The recognition of the existence of the PLC highlights the need for companies to innovate in products. Therefore, the position of its products in reference to the PLC and the forms it adopts is an important element for planning the innovation strategy within the company".

There is a broad consensus in the scientific literature in relation to the fact that the PLC must be taken into account when determining marketing strategies to follow. Kaldasch (2015) and Moon (2005) point out that the knowledge of the PLC allows the positioning of product to improve as well as improves the efficiency of Marketing strategies in companies. Shankar et al. (1999), Rink and Swan (1979) and Palacios (2013) highlight that a correct knowledge of the evolution of some variables along the phases of the PLC is a relevant factor in the business strategy.

The analysis of the PLC is very important for companies since it allows them to be prepared and to use its forecasting as a tool to plan strategically the investment in innovation and Marketing. Therefore, its knowledge and development should be a scientific challenge for the coming years. Saffo (2007) supports this position stating that "the art of forecasting is to identify an $\mathrm{S}$ curve when it begins to emerge, well before its inflection point". In addition, it has been proved (Qualls, Olshavsky, \& Ronald, 1981; Shu et al., 2015) that the sales behaviour of the most recent innovations shows a progressive shortening of the life cycle duration, especially in the introduction and growth phases.

Currently, the scientific literature has studied separately the PLC and the conversion rate, considering that the latter variable does not undergo modifications throughout the PLC. Therefore, the main objective of this article is to study the behaviour of the conversion rate throughout the Product Life Cycle (PLC) of a durable consumer product, as opposed to the recurrent use of the sales variable. Our aim is to deepen in the analysis of the behaviour of the conversion rate throughout each of the phases of the PLC. This will reveal opportunities to create a new business decision methodology that allows the efficiency of the Marketing and sales departments to increase and develop the most appropriate strategies.

In this regard, researchers consider that this article could be a great opportunity within the scientific landscape and an ambitious challenge that opens a new line of research around the atypical behaviours of the conversion rate along the phases of the PLC. This base grounds and gives importance to the research developed in this document. The originality of the finding (an atypical behaviour of the conversion rate along each of the phases of the PLC) can entail a new line of research.

The aim of the article is to use a variable of measurement different from the sales variable to determine the evolution of the life cycle of the product. The parameter studied is the conversion rate and we demonstrate with a time series analysis that the temporal evolution of the series itself, draw the phases of the cycle, so that, the evolution of the series itself fits perfectly the phases of the cycle of the product. The authors dated in a previous article the phases of the cycle for this specific product by using the Bass model methodology (Galiano, Rodríguez, \& Saco, 2018). So the aim of this article is not to do the same but to apply a time series analysis to corroborate that the evolution of the series itself draw the life cycle of the product, and this happens when the conversion rate variable is used. 


\section{Theoretical Framework}

\subsection{Product Life Cycle Literature}

In this section, we have made a review thorough the PLC literature (Tab. 1). In this search, we have found that articles refer to the number of sales as a single variable for the PLC analysis, not having found any evidence about the use of a different variable.

Despite the dominant use of the sales variable in the PLC analysis, different

\begin{tabular}{|c|c|c|c|c|}
\hline \multirow{2}{*}{$\begin{array}{c}\text { Tab. 1: } \\
\text { Variable } \\
\text { used }\end{array}$} & \multicolumn{4}{|c|}{ Summary of the revision: theoretical framework about the PLC analysis - Part 1} \\
\hline & Area of application & Research object & Study limitations & Sources \\
\hline Sales & \begin{tabular}{|l|} 
Sales of 314 \\
industrial vendors
\end{tabular} & $\begin{array}{l}\text { Launch new } \\
\text { products }\end{array}$ & $\begin{array}{l}\text { First years of product } \\
\text { launch }\end{array}$ & Fu (2009) \\
\hline Sales & $\begin{array}{l}\text { Sales of } \\
\text { technological } \\
\text { products }\end{array}$ & $\begin{array}{l}\text { PLC prediction } \\
\text { model }\end{array}$ & $\begin{array}{l}\text { This research uses } \\
\text { historical data. }\end{array}$ & $\begin{array}{l}\text { Orbach \& Fruchter } \\
(2014)\end{array}$ \\
\hline Sales & $\begin{array}{l}\text { The sales of } 29 \\
\text { brands }\end{array}$ & $\begin{array}{l}\text { Introduction in new } \\
\text { markets }\end{array}$ & $\begin{array}{l}\text { Little depth of the PLC } \\
\text { of the product }\end{array}$ & Shankar et al. (1999) \\
\hline Sales & $\begin{array}{l}\text { Sales in new } \\
\text { products and PLC }\end{array}$ & Analysis of the PLC & $\begin{array}{l}\text { No benefits are } \\
\text { defined in the } \\
\text { relationship between } \\
\text { both variables }\end{array}$ & Suomala (2004) \\
\hline $\begin{array}{l}\text { Sales } \\
\text { and prize }\end{array}$ & $\begin{array}{l}\text { The evolution of } \\
\text { sales and price }\end{array}$ & Analysis of the PLC & $\begin{array}{l}\text { Behaviour of supply } \\
\text { and demand }\end{array}$ & Kaldasch (2015) \\
\hline Sales & $\begin{array}{l}\text { Sales analysis } \\
8 \text { products in } 9 \\
\text { countries }\end{array}$ & Analysis of the PLC & $\begin{array}{l}\text { Analyze durable } \\
\text { goods }\end{array}$ & Palacios (2013) \\
\hline Sales & $\begin{array}{l}\text { Purchase intention } \\
\text { of potential } \\
\text { customers }\end{array}$ & $\begin{array}{l}\text { Launch new } \\
\text { products }\end{array}$ & $\begin{array}{l}\text { Absence of analysis } \\
\text { of purchase decisions }\end{array}$ & $\begin{array}{l}\text { Briede-Westermeyer } \\
\text { et al. (2016) }\end{array}$ \\
\hline Sales & Sales of 3 products & Analysis of the PLC & $\begin{array}{l}\text { Absence of the } \\
\text { influence of customs }\end{array}$ & Ratcliff (2016) \\
\hline Sales & $\begin{array}{l}\text { Evolution of sales } \\
\text { over time }\end{array}$ & $\begin{array}{l}\text { Launch new } \\
\text { products }\end{array}$ & $\begin{array}{l}\text { Absence of market } \\
\text { size analysis }\end{array}$ & $\begin{array}{l}\text { Cetinkaya \& Thiele } \\
\text { (2016) }\end{array}$ \\
\hline Sales & $\begin{array}{l}\text { Sales of General } \\
\text { Electric }\end{array}$ & Conversion rate & $\begin{array}{l}\text { Analyze sales } \\
\text { in a market }\end{array}$ & Ledingam (2006) \\
\hline Sales & $\begin{array}{l}\text { Mobile sales and } \\
\text { internet access }\end{array}$ & $\begin{array}{l}\text { Sector of } \\
\text { communications and } \\
\text { the digital economy }\end{array}$ & $\begin{array}{l}\text { Absence of adoption } \\
\text { patterns between } \\
\text { countries }\end{array}$ & Weissmann (2008) \\
\hline Sales & $\begin{array}{l}\text { Sales in the } \\
\text { electricity market }\end{array}$ & PLC & $\begin{array}{l}\text { Absence of business } \\
\text { implications }\end{array}$ & $\begin{array}{l}\text { Hachula \& Schmeidel } \\
\text { (2016) }\end{array}$ \\
\hline
\end{tabular}




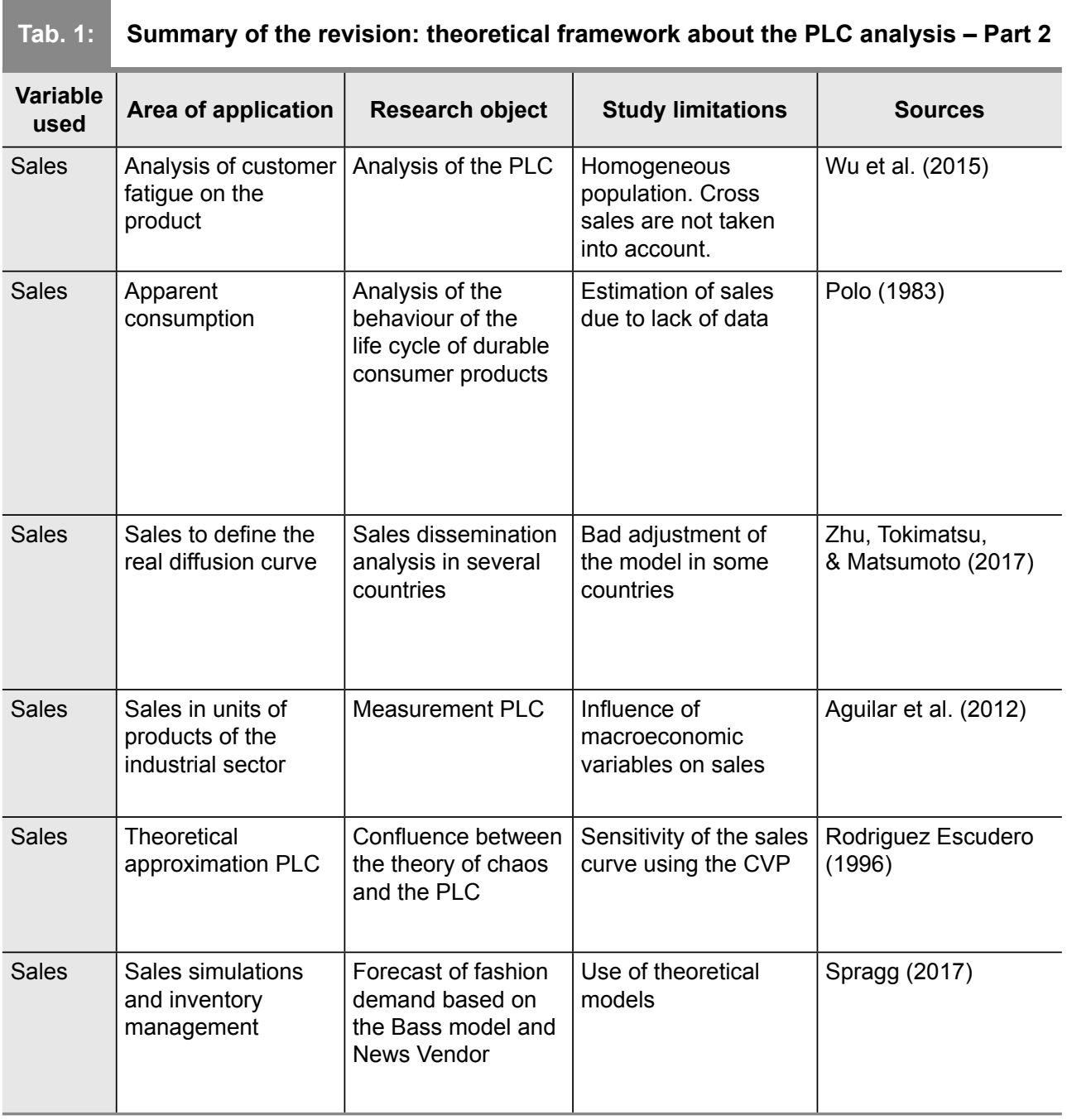

researchers (Rodríguez Escudero, 1996; Aguilar et al., 2012; Muñiz-Ferrer, 2008; Mahajan, Muller, \& Bass, 1979) corroborate that the sales variable is not the best measurement parameter for the analysis of the PLC. The argument, that these authors follow, is that the sales variable is affected by economic and sociodemographic variables, as well as the evolution of the complementary markets, which dismisses its use to make long-run forecasts based on this variable. Thus, it could be that, the anomalous behaviour of the PLC was caused by the influence of macroeconomic phenomena that are alien to the company, but which have a marked effect on the behaviour of the sales variable and, consequently, on the analysis of the PLC. Camacho and Galiano (2009) show the influence of macroeconomic variables on the economic cycle, and they prove how they affect to microeconomic variables such as personal income and, consequently, the purchasing capacity of consumer.

Therefore, the authors consider that it is important for companies not only to use the sale variable to know the situation of their products. On the contrary, this research proposes that companies can handle other types of parameters, such as the conversion rate, to 
assess the effectiveness of their Marketing and sales departments, and to improve the management of the phases of the PLC.

\subsection{Conversion Rate}

The conversion rate $(C R)$ is a fundamental parameter widely used to assess the effectiveness of the Marketing and sales departments, to evaluate the effect of Marketing and operational actions and/or to detect aspects that do not work properly and, consequently, to adopt strategic decisions. It can also be used to forecast the future trend of some business variables or to identify the most profitable customers. These will help companies to make better investment and to take better Marketing decisions.

For Choe (2016) the studies about the conversion rate are a standard technique whereby marketing specialists evaluate the effectiveness of advertising. Literature in this area have evolved to include the decisions of potential customers; nevertheless, there are few comparative articles (Choe, 2016, p. 143).

Many researches analyse the impact of the Marketing actions focused on increasing the traffic of clients to the establishment. The absence of data in the past about the traffic of clients leads to the exclusive use of sales and earnings data (Walters \& Rinne, 1986; Walters \& Mackenzie, 1988). Perdikaki et al. (2012) are pioneers in using real traffic data (using traffic counters installed at store entrances). Their objective was to relate the role of the labour factor to the customer traffic and to the sales results in a store. These authors point out that an increase in customer traffic does not necessarily increase the conversion rate, since too much public and/or poor planning of marketing actions can have a negative impact on consumer behaviour, such as queues, stressed personnel, overwhelm, bad image can be so dangerous, that defrauded customers will not return to the stores and will even speak ill of the establishment).

It is very important to attempt that client has a good experience in the establishment, so that she can repeat her visit in the future. In this line, Söderlund (2014) focuses his research on the following hypothesis: having a positive visit in a store, but without a purchase, can lead to a purchase in another store of the competition. So far, the investigations aimed at the satisfaction of the customers who bought and not those who left without buying. It is essential to convert these visitors into real buyers to increase the conversion rate. However, visitors who left without buying should not be considered as lost consumers, since their visit, if it produces a good impression on them, it could imply a future purchase and could have an impact on the perception of the client in relation to the brand image of establishment (Bloch \& Richins, 1993).

Seiler and Yao (2017) carried out another novel empirical work. They not only analyse the traffic of clients, but also the movements within the establishments, the exposure to advertising and how they influence the conversion in supermarkets. Data set come from 26-day observation of a hypermarket in California, and completed this information with exposure to television advertising through the IRI data set. The conclusions of the article showed that television advertising increases customer traffic at this point of sale, but does not improve conversion rates.

In spite of those reviewed article, which analyse the customer traffic, we have detected a lack of empirical analysis on the economic impact of this traffic at the points of sale. Knowing this traffic more rigorously will help to improve positively the results at the points of sale (Netessine et al., 2010; Rodríguez, OlartePascual, \& Saco, 2015).

In other line, there are relevant studies that analysed the conversion rate based on the exposure of potential consumers to advertising (Sahni, 2015). This research uses a nested test to assess the retention in memory of advertising in restaurants across 11 countries. The result of the research is that a periodic and coordinated exposure of advertising to consumers improves sales conversion rates.

There are also studies that corroborate that the computation of the conversion rate is very important because it constitutes the metric to measure the profitability of the business (Sood \& Kumar, 2017). These studies add a perspective that focuses on profitability to identify the most profitable customers.

The concept of conversion rate $(\mathrm{CR})$ has also be used in online stores to assess the effectiveness of their communication actions. Although e-commerce is a recent phenomenon compared to physical commerce, there are more studies on conversion rates online than on physical commerce. Puente (2016) considers 
the conversion rate as a crucial parameter in the e-commerce, and he points out that the fact of increasing a few tenths this figure will increase considerable the volume of income. Therefore, to invest time and resources in analysing what is wrong and try new alternatives to see which reports more benefits is a good investment if this achieve to increase the conversion on the web. In the same line, Saura et al. (2017) carried out an investigation in which, as a conclusion,
KPIs (activity indicators) were proposed to improve the conversion rate and, therefore, the effectiveness of digital marketing policies. The influence of friends and influencers on social networks has also been analysed, as well as how they influence the rate of conversion in sales (Zhu et al., 2016).

Then, we summarise the revision of the Theoretical Framework about the use of the conversion rate (Tab. 2).

\begin{tabular}{|c|c|c|c|c|}
\hline ab. 2: & $\begin{array}{l}\text { mmary of the re } \\
\text { the conversion } r\end{array}$ & $\begin{array}{l}\text { on: Theoretical I } \\
\text { - Part } 1\end{array}$ & nework about the & \\
\hline $\begin{array}{c}\text { Variable } \\
\text { used }\end{array}$ & Area of application & Research object & $\begin{array}{l}\text { The study content } \\
\text { and limitations }\end{array}$ & Sources \\
\hline $\begin{array}{l}\text { Conversion } \\
\text { rate }\end{array}$ & $\begin{array}{l}\text { Retail clothing data: } \\
\text { store traffic and } \\
\text { sales performance }\end{array}$ & $\begin{array}{l}\text { Analyse the impact } \\
\text { of traffic between } \\
\text { sales and their } \\
\text { components. }\end{array}$ & $\begin{array}{l}\text { Importance of in- } \\
\text { store operations for } \\
\text { driving the financial } \\
\text { performance of } \\
\text { retailers }\end{array}$ & $\begin{array}{l}\text { Perdikaki et al. } \\
(2012)\end{array}$ \\
\hline $\begin{array}{l}\text { Conversion } \\
\text { rate/sales }\end{array}$ & Clothing retailer & \begin{tabular}{|l} 
Retail industry \\
analysis to identify \\
the operational \\
challenges faced \\
by retail managers \\
and operational \\
managers
\end{tabular} & $\begin{array}{l}\text { Retail management } \\
\text { should focus: } \\
\text { Conversion rate, } \\
\text { electronic commerce, } \\
\text { Social Media }\end{array}$ & Fisher (2013) \\
\hline $\begin{array}{l}\text { Conversion } \\
\text { rate }\end{array}$ & $\begin{array}{l}\text { Shopping center } \\
\text { Sweden Clothing } \\
\text { retailer (Inditex, } \\
\text { H\&M) }\end{array}$ & $\begin{array}{l}\text { The effects of } \\
\text { satisfaction derived } \\
\text { from a specific visit } \\
\text { to the store about } \\
\text { the customer's } \\
\text { relationship with } \\
\text { other stores (store } \\
\text { creation) }\end{array}$ & $\begin{array}{l}\text { The reality of retail } \\
\text { indicates that many } \\
\text { customers leave the } \\
\text { stores without making } \\
\text { purchases despite the } \\
\text { satisfaction of the visit }\end{array}$ & Söderlind (2014) \\
\hline $\begin{array}{l}\text { Bass } \\
\text { diffusion } \\
\text { theory/ } \\
\text { sales/ } \\
\text { conversion } \\
\end{array}$ & $\begin{array}{l}\text { Empirical data } \\
\text { of technological } \\
\text { services company } \\
\text { in } 7 \text { countries for } 6 \\
\text { years }\end{array}$ & $\begin{array}{l}\text { Identify the } \\
\text { most profitable } \\
\text { customers. }\end{array}$ & $\begin{array}{l}\text { Identify the most } \\
\text { profitable customers. }\end{array}$ & $\begin{array}{l}\text { Sood \& Kumar } \\
(2017)\end{array}$ \\
\hline $\begin{array}{l}\text { Diffusion } \\
\text { model/sales }\end{array}$ & Business field & $\begin{array}{l}\text { They develop an } \\
\text { analytical model to } \\
\text { study the strategy of } \\
\text { the company related } \\
\text { to time and prices } \\
\text { in the dissemination } \\
\text { of products. Review } \\
\text { dissemination } \\
\text { models }\end{array}$ & $\begin{array}{l}\text { It shows how the } \\
\text { price and time } \\
\text { policy affects the } \\
\text { strategic behaviour of } \\
\text { consumers. }\end{array}$ & Guo \& Chen (2017) \\
\hline $\begin{array}{l}\text { Conversion } \\
\text { rate }\end{array}$ & Digital market & $\begin{array}{l}\text { Analysis of the } \\
\text { purchase behaviour } \\
\text { of digital customers }\end{array}$ & $\begin{array}{l}\text { The investment in } \\
\text { ecommerce improves } \\
\text { the conversion rate in } \\
\text { sales. }\end{array}$ & Puente (2016) \\
\hline
\end{tabular}




\begin{tabular}{|c|c|c|c|c|}
\hline b. 2: & \multicolumn{4}{|c|}{$\begin{array}{l}\text { Summary of the revision: Theoretical Framework about the use } \\
\text { of the conversion rate - Part } 2\end{array}$} \\
\hline $\begin{array}{l}\text { Conversion } \\
\text { rate }\end{array}$ & QQ Social Network & $\begin{array}{l}\text { Influence of friends } \\
\text { and influencers in } \\
\text { social networks on } \\
\text { buying behaviour }\end{array}$ & $\begin{array}{l}\text { The influence of } \\
\text { friends, who have } \\
\text { made purchases } \\
\text { before, is the biggest } \\
\text { influence. }\end{array}$ & Zhu et al. (2016) \\
\hline $\begin{array}{l}\text { Conversion } \\
\text { rate }\end{array}$ & $\begin{array}{l}\text { Online restaurants } \\
\text { in } 11 \text { countries }\end{array}$ & $\begin{array}{l}\text { Analysis of the } \\
\text { exposure influence } \\
\text { of restaurant } \\
\text { consumers }\end{array}$ & $\begin{array}{l}\text { The repeated } \\
\text { exposure of } \\
\text { consumers to } \\
\text { advertising increases } \\
\text { the conversion rate. }\end{array}$ & Sahni (2015) \\
\hline $\begin{array}{l}\text { Conversion } \\
\text { rate }\end{array}$ & $\begin{array}{l}\text { Marketing strategies } \\
\text { in the digital } \\
\text { environment }\end{array}$ & $\begin{array}{l}\text { Review of digital } \\
\text { marketing strategies }\end{array}$ & $\begin{array}{l}\text { Proposal of some } \\
\text { KPI's to improve the } \\
\text { conversion rate in } \\
\text { sales }\end{array}$ & Saura et al. (2017) \\
\hline $\begin{array}{l}\text { Conversion } \\
\text { rate }\end{array}$ & $\begin{array}{l}30,814 \text { American } \\
\text { travelers who } \\
\text { purchased their } \\
\text { tickets online }\end{array}$ & $\begin{array}{l}\text { Analysis of the } \\
\text { influence of } \\
\text { advertising on the } \\
\text { conversion into } \\
\text { sales }\end{array}$ & $\begin{array}{l}\text { The model } \\
\text { Destinarion } \\
\text { Advertisement } \\
\text { Response (DAR } \\
\text { model) is a model } \\
\text { suitable for the } \\
\text { analysis of the } \\
\text { conversion rate. }\end{array}$ & Choe et al. (2017) \\
\hline $\begin{array}{l}\text { Conversion } \\
\text { rate }\end{array}$ & $\begin{array}{l}\text { Observation } \\
\text { during } 26 \text { days } \\
\text { of a supermarket } \\
\text { in California and } \\
\text { completed the } \\
\text { information with IRI } \\
\text { data }\end{array}$ & $\begin{array}{l}\text { Influence of } \\
\text { advertising, traffic } \\
\text { of people and } \\
\text { movements within } \\
\text { the supermarket } \\
\text { related to the } \\
\text { conversion rate }\end{array}$ & $\begin{array}{l}\text { Advertising influences } \\
\text { people's traffic, not } \\
\text { the conversion rate }\end{array}$ & Seiler \& Yao (2017) \\
\hline
\end{tabular}

After the next extensive review of the literature (Tab. 2), we found no evidence about the analysis of the behaviour of the conversion rates in sales along the phases of the PLC. In this context, this article aims to contribute to the joint research of the commercial and marketing management, from the theoretical and practical point of view, deepening in the analysis of the conversion rate (CR) throughout the phases of the Product Life Cycle (PLC). To reach this goal, we propose the following Research Question:

$R Q$ : Does the use of the evolution of the TC along the PLC allow adjusting the marketing and sales strategies, improving the planning and commercial management of the points of sale?

This Research Question will allow us to test the following hypotheses:

H1: The behaviour of the conversion rate $(C R)$ is homogeneous throughout the phases of the PLC, assuming an opportunity for companies that know how to adapt.

H2: The increase in sales volume in the growth phase is due to the improvement in the conversion rate.

\section{Methodology}

\subsection{Data}

Citroën Spain Automobile has provided the information used in this study. Data set was collected during 42 months, from August 2014 to January 2018. The total number of observation is 157,960 clients assisted who have purchased 27,831 vehicles. The observation units were registered from a network of 140 car dealerships located throughout the national territory. This fact enriches the sample and ensures the possibility of making inferences at the national level. The data were obtained from 
the customer treatment software of Citroën that lets you know how many customers were interested in the vehicle (customers assisted) and finally how many bought it (sales). The percentage of sales on customers treated is the conversion rate used in this study.

This paper focuses on a specific model of vehicle, C4 Cactus, which was launched onto the market in August 2014 (at this time we began to collect data) and was finally renewed in January 2018, so we have the complete life cycle for this product.

The evolution in the clients assisted variable shows the following phases in the PLC:

- Introduction of the product in the market: launch period, with an average growth rate of $2.68 \%$.

- Growth of the product in the market: until July 2015 with an average growth rate of $7.35 \%$.

- Maturity-decline of the product in the market: from March 2017 with growth rates remains almost constant, with lower rates compared to the previous phase.

C4 Cactus model is a vehicle of the compact segment (4.16 meters long) with a broad client target: older couples, young couples and single people. This makes it suitable to be analysed due to the wide range of clients included.

\subsection{Variables of Study and Period Analysis}

Data set collect information about the following variables: (1) clients assisted and (2) effective sales.

The conversion rate $(\mathrm{CR})$ is computed from these collected variables as:

$$
C R=E S / C A * 100,
$$

where ES is the number of customers who make a purchase and CA the number of customers that visit the stores, prospective clients.

Following this formula (1), the conversion rate is defined as the number of customer who make a purchase over the total number of clients who visits the establishment. Therefore, this ratio computes the proportion of clients assisted on sales.

Considering the methodology apply in Galiano, Rodríguez and Saco (2018) - where the authors analyse the duration of the product PLC of the C4 Cactus by using the Bass model methodology, and according to the graphical evolution of the variable conversion rate (CR) and its behaviour along the phases of the life cycle of the product showed in Fig. 1, we consider the following periods of analysis:

- Launch phase: August 2014 to January 2015.

- Growth phase: February 2015 to July 2015.

- Maturity phase: July 2015 to March 2017.

- Decline phase: March 2017 to January 2018.

We must not be surprised about the short time considered in the different phases of the PLC. To this respect, it should be considered that, in the automobile sector, the PLC is fiveyears average. That is why the launch phases and growth are shorter since it is sought to achieve a high volume of sales as soon as possible, and to remain across time as long as possible (maturity phase). Also making the phase of the decline briefest.

The conversion rate shows a continued growth until January 2015. This mean that during the launch phase it shows a positive behaviour with an average growth rate of $0.81 \%$, therefore, in this phase of the PLC the values of the conversion rates are high, which would mean that the proportion of clients assisted on sales is high and positive. However, after this period and until July 2015, the growth period, conversion rate behaves negative, on average $-0.52 \%$. These behaviours will be corroborating as significant by our models.

The fall showed during the growth phase evidence a countercyclical behaviour for the conversion rate - we understand the cycle as the product life cycle (PLC) - opposites to the finding of the scientific literature who has always identify the growth phase as the phase in which sales increase the most. However, this increase is not due to an improvement in the conversion rate, but on the contrary, the conversion rate worsens. Therefore, the cause of an increase in sales during the growth phase is due solely and exclusively to an increase in the traffic of clients assisted, even in spite of the negative values of the conversion rates suffered in that phase of the PLC.

From that moment on, there is a growing linear trend in the maturation and decline phase showing ups and downs movements. In spite of these fluctuations, and controlling for them, our model will show a positive and significant trend from the growth phase until March 2017 


\section{Fig. 1: Temporal evolution of the series conversion rate of the $\mathrm{C} 4$ Cactus model}

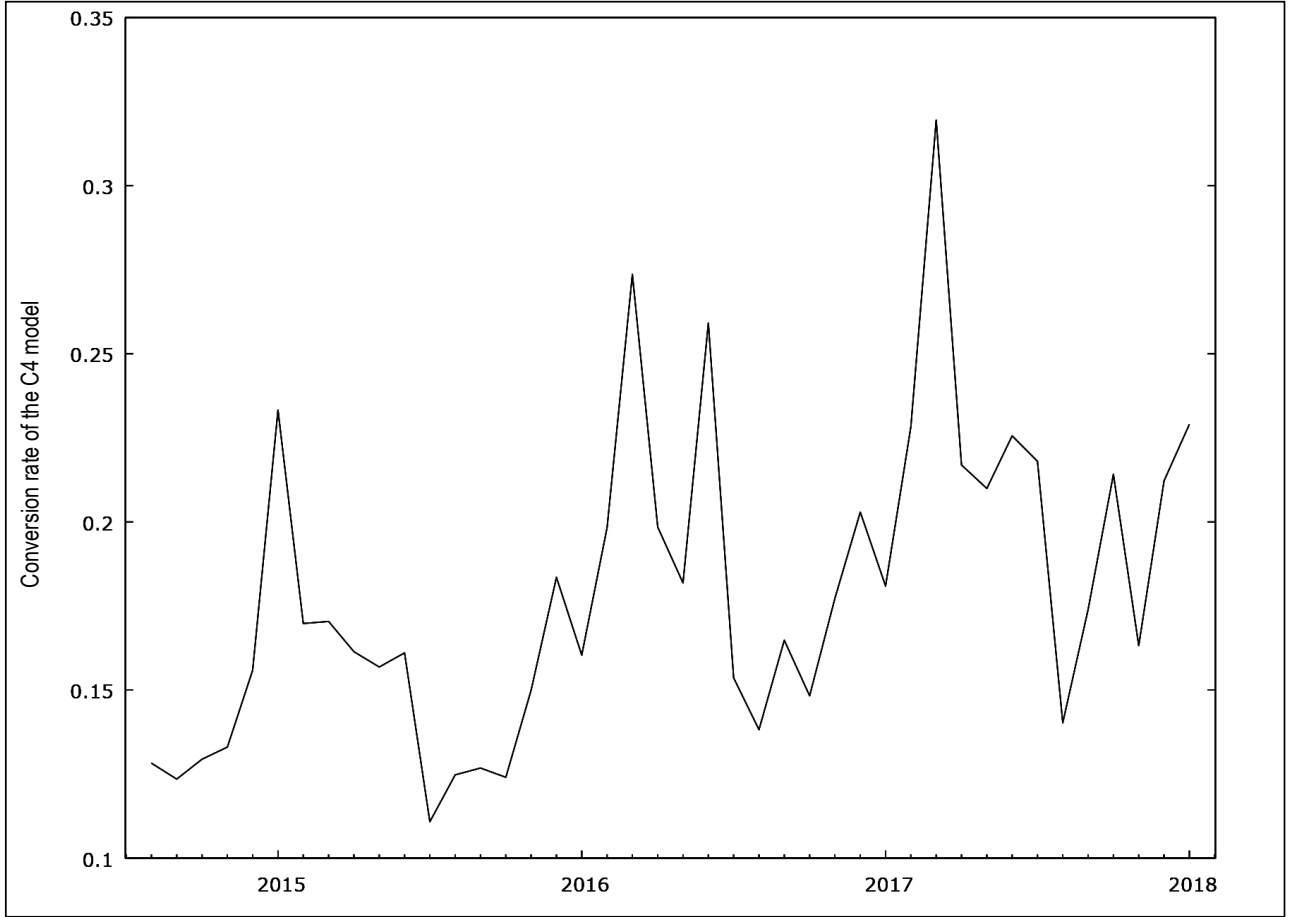

Source: own

(beginning of the maturation phase), and later a negative trend, although not significant (during the decline phase).

As a result, the previous graphic analysis gives us visual evidence about a countercyclical pattern in the conversion rate (CR).

\section{Results}

Results imply two step analysis: first, it is necessary to treat the series in order to capture the best model to explain the behaviour of the series. Second, once we find the true model that define the behaviour of the series, we proceed to analyse if there are temporary moments that are significant across time, and if they have a negative or positive effect on the evolution of the series.

\subsection{Treatment of the Series}

The empirical part deals with the temporal analysis of the conversion rate series, which is computed from assisted clients and sales variable for the period August 2014 to January 2018.

We use Box-Jenking methodology to analyse the evolution of this series (ARIMA models). This methodology goes beyond the simple modelling of the cyclical, trend and seasonal components. Specifically, it focuses on analysing the non-systematic part of the series, random and irregular, trying to identify a pattern of interest in its evolution.

This is a methodology for modelling nonstationary series, so the first step corresponds to the correct treatment of the series to turn it into stationary. We also have to control for seasonality. Subsequently, we follow in the analysis the phases of the Box-Jenkins Methodology: identification, estimation and modelling.

Following the steps previously commented, firstly we observe the original graph of the series (Fig. 1) which leads us to think that the series 


\begin{tabular}{l|c|c|c|c|c} 
& Coefficient & $\begin{array}{c}\text { Standard } \\
\text { deviation }\end{array}$ & t-ratio & p-value & Significance \\
\hline Constant & 0.109828 & 0.0331242 & 3.316 & 0.0023 & $* * *$ \\
\hline Variable in levels & -0.752960 & 0.218942 & -3.439 & 0.0463 & $* *$ \\
\hline $\begin{array}{l}\text { Variable in First } \\
\text { difference }\end{array}$ & 0.222135 & 0.217621 & 1.021 & 0.3150 & \\
\hline $\begin{array}{l}\text { Variable in Second } \\
\text { differences }\end{array}$ & 0.0223314 & 0.184082 & 0.1213 & 0.9042 & \\
\hline $\begin{array}{l}\text { Variable in Third } \\
\text { differences }\end{array}$ & 0.467077 & 0.160176 & 2.916 & 0.0064 & $*$ \\
\hline Trend & 0.00120352 & 0.000659627 & 1.825 & 0.0774 & $*$ \\
\hline
\end{tabular}

Source: own

Note: The significance of the estimated parameters is given next to each estimation: ${ }^{*} 5-10$ per cent; ${ }^{* *} 1-5$ per cent; $* * *<1$ per cent.

\section{Tab. 4: Estimation of the conversion rate SARIMA(2,2,1)}

\begin{tabular}{l|l|l|c|c|c|} 
& $\begin{array}{c}\text { Estimated } \\
\text { coefficients }\end{array}$ & $\begin{array}{l}\text { Standard } \\
\text { deviation }\end{array}$ & t-ratio & p-value & Significance \\
\hline $\mathrm{AR}(1)$ & -0.734077 & 0.142660 & -5.146 & $2.67 \mathrm{e}-07$ & ${ }^{* * *}$ \\
\hline $\mathrm{AR}(2)$ & -0.627765 & 0.136051 & -4.614 & $3.95 \mathrm{e}-06$ & ${ }^{* * *}$ \\
\hline $\mathrm{MA}(1)$ & -1.00000 & 0.236775 & -4.223 & $2.41 \mathrm{e}-05$ & ${ }^{* * *}$ \\
\hline
\end{tabular}

Source: own

Notes: Constant is not included in the estimation because it is not significant. Dependent variable in logarithms. SARIMA(2,1,2) model estimation. Estimation uses the Kalman filter (MV). Standard deviation based on the Hessian. The significance of the estimated parameters is given next to each estimation: * $5-10$ per cent; ${ }^{* *} 1-5$ per cent; ${ }^{* *}<1$ per cent.

presents seasonality, with a marked tendency and changes in its variability, as a result we will consider the series in logarithms. Secondly, we deal with the non-stationarity. To this respect, the Dickey Fuller test (Tab. 3) shows the presence of unit roots. To deal with nonstationarity issue, we consider the logarithms of the series in second differences. We also consider a degree of seasonal differentiation.

We estimate a $\operatorname{SARIMA}(2,2,1)$ model with one seasonal lag. In the estimation (Tab. 4), all the estimated coefficients are significant at $1 \%$, and we observe non-stationary performance (white noise) in the residual of the estimated model (Fig. 2).

\subsection{Estimation of the Model with Temporary Dummy Variables}

In this analysis, the objective is to identify possible temporary co-movement between the serie and the different phases of the PLC. With that purpose, we define the following temporary dummy variables, which take the value 1 if the series is in the mentioned period and 0 on the contrary:

- DJanuary2015 = 1 if launch period (August 2014 to January 2015);

- DJuly2015 = 1 if growth period (February 2015 to July 2015);

- DMarch2017 = 1 if maturity phase (July 2015 to March 2017);

- DJanuary2018 = 1 if decline phase (April 2017 to January 2018). 


\section{Fig. 2: Correlogram of the residual}

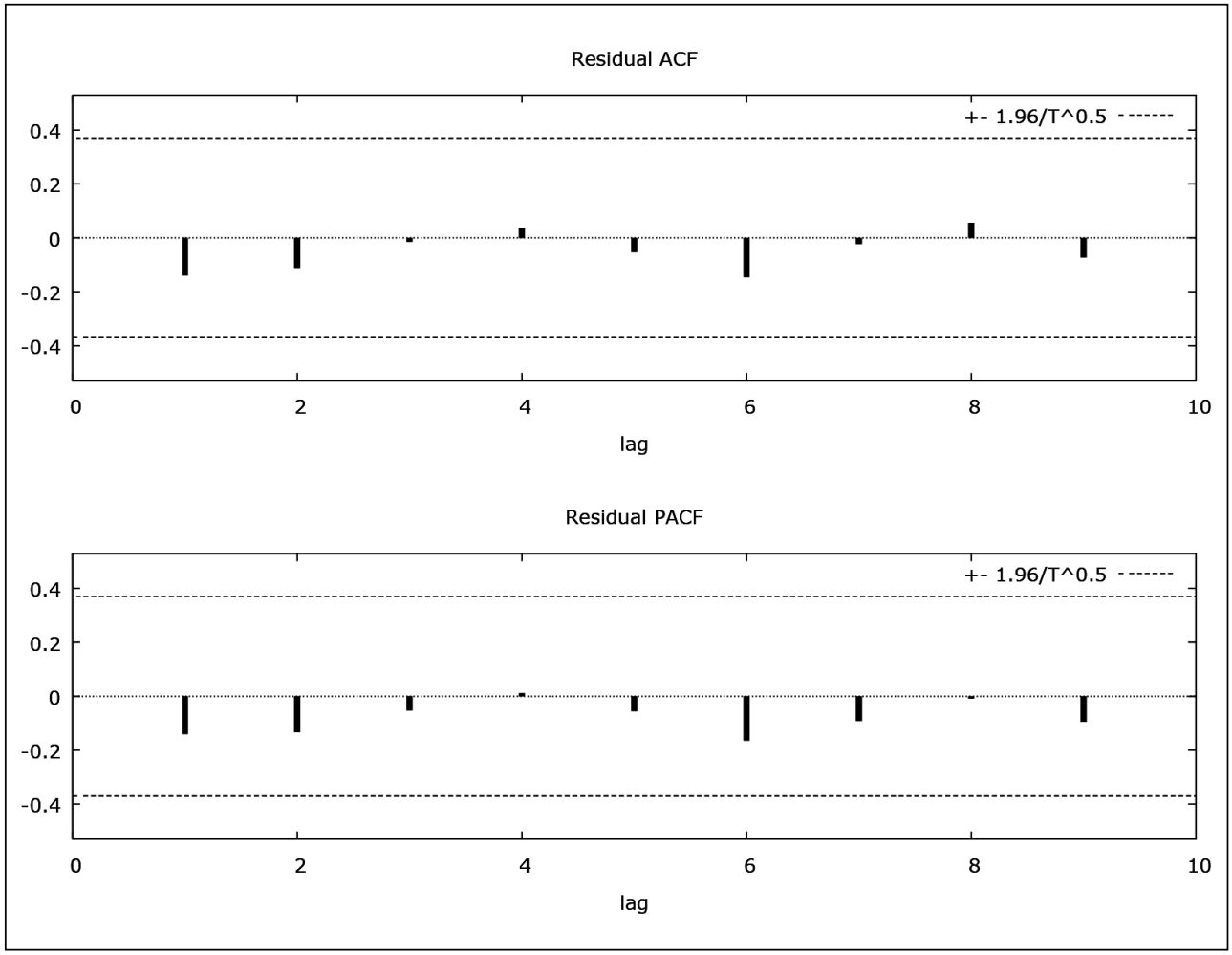

Source: own

The effect of the temporary dummy variables will be analysed using separate regressions, in order to isolate the effect of each of them. Doing that, in each regression is going to be considered the evolution of the series within each period opposite to its evolution in a different period. Next, it is summarised the estimation results (Tab. 5).

We observe that the launch period dummy variable (DJanuary2015) is positive (significant at $1 \%, p$-value equal to 0.001$)$, corroborating a positive and increasing behaviour for the conversion rate during this period. The opposite behaviour is occurred during the growth period (DJuly2015). Along this phase, the conversion rate shows a negative behaviour (significant at $1 \%$, p-value equal to 0.001 ). Therefore, the model throws evidence about a negative behaviour of the conversion rate along the growth period, opposite to the scientific literature that has always considered it as a splendour period for sales.

For the maturity phase, the evolution of the conversion rate is positive (significant at $10 \%$ ), which shows a change in trend once the growth phase has been overcome. This parameter indicates that the conversion rate is positive and stable in the maturity phase. After this, in the decline phase (DJanuary2018), the estimation is negative, although not significant $(p$-value $=0.2825)$.

\section{Discussion}

In view of the results evidence by the BoxJenkins methodology and the regression analysis with the temporary dummy variables, we detail the following results for the behaviour of the conversion rate $(\mathrm{CR})$ throughout the life cycle of the C4 Cactus model: 
Tab. 5: Estimation of the time series model using temporal dummy variables

\begin{tabular}{l|c|l|r|r|c} 
& $\begin{array}{c}\text { Estimated } \\
\text { coefficients }\end{array}$ & $\begin{array}{l}\text { Standard } \\
\text { deviation }\end{array}$ & t-ratio & p-value & Significance \\
\hline DJanuary2015 & 0.342555 & 0.103684 & 3.304 & 0.0010 & $* * *$ \\
\hline DJuly2015 & -0.228169 & 0.0694609 & -3.285 & 0.0010 & $* * *$ \\
\hline DMarch2017 & 0.170372 & 0.0889512 & 1.915 & 0.0554 & $*$ \\
\hline DJanuary2018 & -0.135210 & 0.125810 & -1.075 & 0.2825 & \\
\hline
\end{tabular}

Source: own

Notes: Constant is not included in the estimation because it is not significant. Dependent variable in logarithms. $\operatorname{SARIMA}(2,1,2)$ model estimation. Estimation uses the Kalman filter (MV). Standard deviation based on the Hessian. The significance of the estimated parameters is given next to each estimation: ${ }^{\star} 5-10$ per cent; ${ }^{* \star} 1-5$ per cent; ${ }^{\star \star *}<1$ per cent.

- Launch phase: The conversion rate takes high values showing a positive behaviour and indicating that the proportion of clients assisted on sales is high and positive.

- Growth phase: Conversion rate falls along this period corroborating a countercyclical behaviour (significant at $1 \%$ ). So that, the conversion rate does not present a positive behaviour in the algid phase of sales.

- Maturity and decline phase: The conversion rate behaves as expected, with a positive and significant evolution in the maturity phase, and negative evolution, but not significant, in the decline phase.

This atypical and unknown behaviour in the conversion rate can be used throughout the PLC to improve the effectiveness of commercial management policies. Therefore, the authors answer the Research Question and, also, they analyse each of the research hypotheses:

$R Q$ : Does the use of the evolution of the TC along the PLC allow adjusting the marketing and sales strategies, improving the planning and commercial management of the points of sale?

Affirmative: This article opens a new line of research from the finding of a heterogeneous and unexpected behaviour of the conversion rate in sales along the phases of the PLC. This finding revels to the Marketing and sales department that is crucial to catch traffic of clients to the point of sales during the launch period, since at this point of the PLC the conversion rate reaches the peak.

H1: The behaviour of the $C R$ is homogeneous throughout the phases of the
PLC, assuming an opportunity for companies that know how to adapt.

Refused. It has been revealed throughout the empirical analysis that the conversion rate has not a homogeneous behaviour along the PLC, on the contrary it shows a countercyclical evolution along the growth phase. This fact has been unknown before this research.

This unexpected behaviour of the conversion rate has wide and deep implications in the Marketing and sales departments since it shows the way to redirect its policies in order to allocate their resources more efficiently.

H2: The increase in sales volume in the growth phase is due to the improvement in the conversion rate.

Rejected. The positive evolution of sales is not the result of an improvement in the conversion rate. The change in the trend from negative to positive from the growth phase to the maturity phase is particularly striking, which highlights the marked countercyclical nature of the conversion rate in the peak period of sales.

The scientific literature (Fu, 2009; BriedeWestermeyer et al., 2016; Cetinkaya \& Thiele, 2016) had focused the policies of these departments along the launching phase of the PLC with the purpose of guiding policies to the discovery of the product. On the contrary, our research suggests that they should considered policies aimed to attract clients to the points of sales during the launch phase because at this time their propensity to purchase is the highest; consequently, the efficiency of the Marketing and sales departments will improve. 


\section{Conclusions}

This article performs an empirical research that evidences the existence of a heterogeneous and unexpected behaviour of the conversion rate in sales along the phases of the PLC. Consequently, this work proposes to use this atypical behaviour with the aim of orientating more efficiently the business sales and to attract clients to the point of sales, mainly during the launch phase of the PLC.

This article is in line with the results obtained in the previous work of Galiano, Rodríguez and Saco (2018) in which, using the Bass model, these authors dated the phases of the PLC in durable consumer products. The research pointed out the importance of defining the phases of the PLC using the assisted clients variable, but the behaviour of the evolution of the conversion rate in sales along the phases of the PLC was not explored; an aspect that the authors consider of great importance. MuñizFerrer (2008) concludes that the conversion rate in sales is a crucial parameter to be analyse in order to improve the results of Marketing and sales departments; consequently, it will improve the efficiency and the forecasting capacity of the sales variable when analysing the PLC. However, there is a gap in the analysis of the conversion rate and its behaviour along the PLC.

Previous scientific literature neither refers nor even proposes a management of the behaviour of the $\mathrm{CR}$ along the phases of the PLC. Moreover, there is neither precedent nor evidence about the existence of a heterogeneous behaviour in the sales conversion rate along the phases of the PLC (Perdiaki et al., 2012; Soderlind, 2014; Choe et al., 2017; Saura, 2017).

However, articles focused on the efforts of the points of sale in the improvement of the conversion rate start to be published (Fisher, 2013). Empirical studies such as this one that evidence a heterogeneous behaviours in the conversion rates variable, will help to increase the efficacy of this parameter. In this sense, the policies focus on the management of the conversion rate will not only increase efficiency but also improve the return on investment making the Marketing and sales policies more profitable (Sood \& Kumar, 2017; Guo \& Chen, 2017). Furthermore, for an adequate management of the conversion rates, activity indicators such as those recommended by
Saura et al. (2017) should be used. These authors point out that not only an effectiveness management analysis of the conversion rate should be carried out, but also those analyses aimed to know the deviations in the results and, consequently, develop corrective actions.

The main empirical result of our research is that the behaviour of the conversion rate is heterogeneous, atypical and different from what expected. Especially striking has been the result of its behaviour along the growth phase, where it shows a countercyclical behaviour (a negative and significant evolution). Consequently, it can be concluded that the increase in sales evidenced in the growth phase is not a consequence of the behaviour of the conversion rate, but of the increase in the traffic of assisted clients to the points of sale. An empirical analysis apply to the collected variables has been used to reach such a conclusion. Concretely, it is used time series analysis over the conversion rate variable, using ARIMA methodology for nonstationary and seasonal series (Box-Jenkins methodology).

As a conclusion, the most relevant finding of this research is to show an unexpected and countercyclical behaviour of the conversion rate along the PLC and to expose the possibilities that this finding offers to the management of the Marketing and sales departments. These departments can used this result to lead more effectively and efficiently their policies and resources. These find open a new and interesting line of research in which the authors of this article intend to deepen in further studies.

The main limitation of this research is the absence of previous scientific literature that analyses the behaviour of the conversion rate variable for the PLC analysis, possibly caused by the repeated use of the sales variable in the scientific community.

Another limitation of this article is that this study focuses on analyzing durable consumer goods in a specific model inside the automotive sector. Although the results are considered to be an important advance, it is not known if this is a particular feature of this sector in the study area or the results can be extrapolated. Therefore, the author recommend to replicate this study in other sectors of activity to compare results. 


\section{References}

Aguilar, S., Ávalos, A. F., Giraldo, D. P., Quintero, S., Zartha, J. W., \& Cortés, F. B. (2012). La Curva en $S$ como Herramienta para la Medición de los Ciclos de Vida de Productos. Journal of Technology Management \& Innovation, 7(1), 238-248. https://dx.doi. org/10.4067/S0718-27242012000100016

Bloch, P. H., \& Richins, M. L. (1983). Shopping Without Purchase: an Investigation of Consumer Browsing Behaviour. Advances in Consumer Research, 10, 389-393.

Briede-Westermeyer, J. C., Cabello Mora, M. B., Pacheco Blanco, B., \& Cartes Sanhueza, J. (2016). Implicación de participantes en la fase de diseño conceptual de un producto. Caso de estudio del impacto de la metodología sistémica en una PYME Chilena. Journal of Science and Technology of the Americas, 41(9), 622-628.

Camacho, M., \& Galiano, A. (2009). The incidence of the 1990's expansion on income distribution. Economics Bulletin, 29(4), 3177-3185.

Cetinkaya, E., \& Thiele, A. (2016). New product launch decisions with robust optimization. Computational Management Science, 13(2), 263-292. https://dx.doi. org/10.1007/s10287-015-0237-y

Choe, Y., Stienmetz, J. L., \& Fesenmaier, D. R. (2017). Measuring Destination Marketing: Comparing Four Models of Advertising Conversion. Journal of Travel Research, 56(2), 143-157. https://dx.doi. org/10.1177/0047287516639161

Fenech, J. P. (2013). The diffusion of new products in Latin America: a new comparative approach. Academia Revista Latinoamericana de Administración, 26(1), 77-107. https://dx.doi.org/10.1108/ARLA-05-2013-0041

Ferreira, F., Faria, J., Azevedo, A., \& Marques, A. L. (2017). Product lifecycle management in knowledge intensive collaborative environments: An application to automotive industry. International Journal of Information Management, 37(1A), 1474-1487. https://dx.doi.org/10.1016/j. ijinfomgt.2016.05.006

Fisher, M. (2013). Foreword: Special Issue on Retail Operations. Production and Operations Management, 22(4), 755-757. https://dx.doi.org/10.1111/poms.12014

Galiano, A., Rodríguez, V., \& Saco, M. (2018). Analysis of the behaviour of the clients assisted and sales variables in the different phases of the product life cycle. European Journal of Management and Business Economics, 27(3), 266-284. https://doi. org/10.1108/EJMBE-01-2018-0005

Gan, S. S., Pujawan, I. N., Suparno, \& Widodo, B. (2015). Pricing decision model for new and remanufactured short-life cycle products with time-dependent demand. Operations Research Perspectives, 2, 1-12. https://doi.org/10.1016/j.orp.2014.11.001

Gauri, D. K., Ratchford, B., Pancras, J., \& Talukdar, D. (2017). An Empirical Analysis of the Impact of Promotional Discounts on Store Performance. Journal of Retailing, 93(3), 283303. https://doi.org/10.1016/j.jretai.2017.06.001

Guo, Z., \& Chen, J. (2012). Multi-Generation Product Diffusion in the Presence of Strategic Consumers. SSRN Electronic Journal. https://doi.org/10.2139/ssrn.2892081

Hachuła, P., \& Schmeidel, E. (2016). The Model of Demand and Inventory in a Decline Phase of the Product Life Cycle. Folia Oeconomica Stetinensia, 16(1), 208-221. https://doi.org/10.1515/foli-2016-0013

Kaldasch, J. (2015). The Product Life Cycle of Durable Goods. British Journal of Economics, Management \& Trade, 10(2), 1-17. https://doi. org/10.9734/BJEMT/2015/20395

Ledingham, D., Kovac, M., \& Locke Simon, H. (2006). La nueva ciencia de la productividad de la fuerza de ventas. Harvard Business Review, 84(10), 104-112.

Mahajan, V., Muller, E., \& Bass, F. M. (1995). Diffusion of New Products: Empirical Generalizations and Managerial Uses. Marketing Science, 14(3_supplement), G79-G88. https://doi.org/10.1287/mksc.14.3.G79

Moon, Y. (2005). Libérese del ciclo de vida del producto. Harvard Business Review, 84(5), 66-74.

Netessine, S., Fisher, M., \& Krishnan, J. (2010). Labor Planning, Execution, and Retail Store Performance: An Exploratory Investigation. SSRN Electronic Journal. https://doi.org/10.2139/ssrn.2319863

Orbach, Y., \& Fruchter, G. E. (2014). Predicting product life cycle patterns. Marketing Letters, 25(1), 37-52. https://doi.org/10.1007/ s11002-013-9239-0

Perdikaki, O., Kesavan, S., \& Swaminathan, J. M. (2012). Effect of Traffic on Sales and Conversion Rates of Retail Stores. Manufacturing \& Service Operations 
Management, 14(1), 145-162. https://doi. org/10.1287/msom.1110.0356

Polo, Y. (1983). Evidencia empírica sobre el ciclo de vida para productos de consumo duradero. Cuadernos Aragoneses de Economía, 7, 61-76.

Puente, N. (2016). Optimizando la conversión del punto de venta online. Revista TELOS, Cuadernos de comunicación e innovación, January-May, 1-7.

Qualls, W., Olshavsky, R. W., \& Michaels, R. E. (1981). Shortening of the PLC: An Empirical Test. Journal of Marketing, 45(4), 76-80. https://doi.org/10.2307/1251474

Ratcliff, R., \& Doshi, K. (2016). Using the Bass Model to Analyze the Diffusion of Innovations at the Base of the Pyramid. Business \& Society, 55(2), 271-298. https://doi. org/10.1177/0007650313479529

Rink, D. R., \& Swan, J. E. (1979). Product life cycle research: A literature review. Journal of Business Research, 7(3), 219-242. https://doi.org/10.1016/0148-2963(79)90030-4

Rodríguez Escudero, A. I. (1996). Una aproximación al ciclo de vida del producto bajo los presupuestos de la Teoría del Casos. Anales de estudios Económicos y Empresariales, 11, 129-156.

Rodríguez, V., Olarte-Pascual, C., \& Saco, M. (2015). ¿Qué distancia recorre el consumidor para comprar un coche? Omniscience. Harvard Deusto Business Research, 4(2), 96-112. https://doi.org/10.3926/hdbr.82

Rodríguez, V., Olarte-Pascual, C., \& Saco, M. (2017). Application of geographical information systems for the optimal location of a commercial network. European Journal of Management and Business Economics, 26(2), 220-237. https:// doi.org/10.1108/EJMBE-07-2017-013

Saffo, P. (2007). Seis reglas para pronosticar eficazmente. Harvard Business Review, 85(7), July, 100-110.

Sahni, N. S. (2015). Effect of temporal spacing between advertising exposures: Evidence from online field experiments. Quantitative Marketing and Economics, 13(3), 203-247. https://doi. org/10.1007/s11129-015-9159-9

Saura, J. R., Palos-Sánchez, P., \& Cerdá Suárez, L. M. (2017). Understanding the Digital Marketing Environment with KPIs and Web Analytics. Future Internet, 9(4), 76-88. https://doi.org/10.3390/fi9040076

Seiler,S., \&Yao,S. (2017). Theimpactofadvertising along the conversion funnel. Quantitative
Marketing and Economics, 15(3), 241-278. https://doi.org/10.1007/s11129-017-9184-y

Shankar, V., Carpenter, G. S., \& Krishnamurthi, L. (1999). The Advantages of Entry in the Growth Stage of the Product Life Cycle: An Empirical Analysis. Journal of Marketing Research, 36(2), 269-276. https://doi.org/10.2307/3152098

Söderlund, M., Berg, H., \& Ringbo, J. (2014). When the customer has left the store: An examination of the potential for satisfaction rub-off effects and purchase versus no purchase implications. Journal of Retailing and Consumer Services, 21(4), 529-536. https://doi.org/10.1016/j.jretconser.2014.04.004

Sood, A., \& Kumar, V. (2017). Analyzing Client Profitability across Diffusion Segments for a Continuous Innovation. Journal of Marketing Research, 54(6), 932-951. https://doi.org/10.1509/jmr.16.0209

Suomala, P. (2004). The life cycle dimension of new product development performance measurement. International Journal of Innovation Management, 08(02), 193-221. https://doi.org/10.1142/S1363919604001039

Walters, R. G., \& MacKenzie, S. B. (1988). A Structural Equations Analysis of the Impact of Price Promotions on Store Performance. Journal of Marketing Research, 25(1), 51-63. https://doi.org/10.2307/3172924

Weissmann V. (2008). Difusión de nuevas tecnologías y estimación de la demanda de nuevos productos: un análisis comparativo entre Argentina y EEUU. Palermo Business Review, 1, 5-17.

Wu, M., Wang, L., \& Li, M. (2015). An approach based on the Bass model for analyzing the effects of feature fatigue on customer equity. Computational and Mathematical Organization Theory, 21(1), 69-89. https://doi.org/10.1007/ s10588-014-9177-2

Zhu, Y., Tokimatsu, K., \& Matsumoto, M. (2017). Study on the Diffusion of NGVs in Japan and Other Nations Using the Bass Model. In M. Matsumoto, K. Masui, S. Fukushige, \& S. Kondoh (Eds.), Sustainability Through Innovation in Product Life Cycle Design, (pp. 765-778). Singapore: Springer Singapore. https://doi.org/10.1007/978-981-10-0471-1_52

Zhu, Z., Wang, J., Wang, X., \& Wan, X. (2016). Exploring factors of user's peerinfluence behaviour in social media on purchase intention: Evidence from QQ. Computers in Human Behaviour, 63, 980-987. https://doi. org/10.1016/j.chb.2016.05.037 